\title{
IMPORTANCE OF MARKETING STRATEGY FOR ACHiEvement of Competitive Advantage of Croatian Road Transporters
}

\author{
BENDEKOVIC, J.; SIMONIC, T. \& NALETINA, D.
}

Abstract: Much attention was not given to marketing and marketing activities of Croatian road transporters. As the financial crisis had a strong impact on this industry as well, and taking into consideration that Croatia has joined the European Union which increased the competition, there is clear need for research on the sources of competitive advantage of road transporters, especially of possibility of achievement competitive advantage based on the adequate marketing strategy. Due to that, the aim of this paper is to conduct research on importance of marketing strategy in Croatian road industry and to propose characteristics of marketing strategy that should ensure achievement of competitive advantage to Croatian road transporter, and to define guidance how providers of transport services can improve the level of their service.

Key words: Croatia, competitive advantage, marketing strategy, road industry
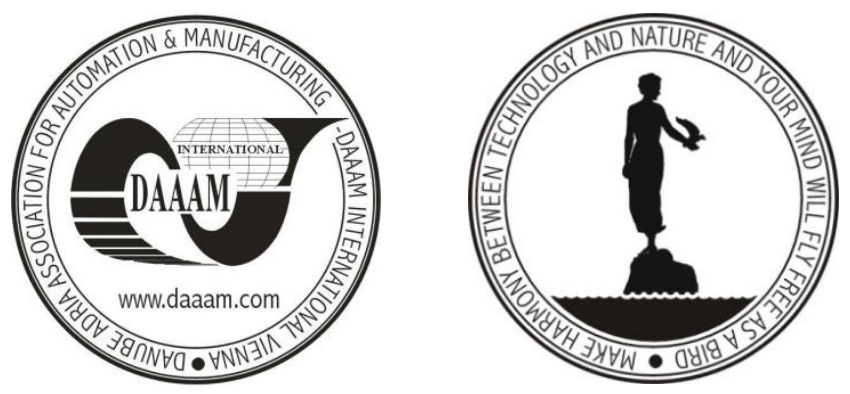

Authors' data: Univ.Prof. Dr. Sc. Bendekovic, J[adranka]*; Simonic, T[in]**; Naletina, D[ora]*, *Faculty of Economics and Business, J. F. Kennedy 6, 10000, Zagreb, Croatia, ** ZB trans d.o.o., Vocinska 12, 10040 Zagreb, Croatia, jadranka.bendekovic@efzg.hr, tin.simonic@gmail.com,dora.naletina@efzg.hr

This Publication has to be referred as: Bendekovic, J[adranka]; Simonic, T[in] \& Naletina, D[ora] (2014). Importance of Marketing Strategy for Achievement of Competitive Advantage of Croatian Road Transporters, Chapter 21 in DAAAM International Scientific Book 2014, pp.257-266, B. Katalinic (Ed.), Published by DAAAM International, ISBN 978-3-901509-98-8, ISSN 1726-9687, Vienna, Austria DOI: $10.2507 /$ daaam.scibook.2014.21 


\section{Introduction}

The process of globalization has strongly affected the market of transport services. The concentration of production and distribution centres require extra effort from transport operators with the aim of ensuring necessary capacities for the easy functioning of the entire supply chain. Market liberalization has ensured the free circulation of cargo within the borders of European Union. Clients require new forms of transport activities from transporters and the establishment of long-term business relationships.

To be able to arrive at quality business decisions, transporters must consider the following market demands:

1. Due to increased concentration of industry and production on the global level, volume of transactions for a single customer increases;

2. Increased demand in the transport activity requires a higher level of service (delivery at the appointed time, multiple deliveries);

3. Requested specialization require huge investments;

4. Emphasis on additional logistics services (warehousing, packaging, labelling, etc.).

All mentioned above requires from the transporters to change their current thinking about the market and its customers. Due to that, this paper analyses the importance of marketing aiming to improve business results. Research was conducted with the object of determining the value for customers based on three groups of service characteristics (fee for service, service quality and service availability) and to measure customer satisfaction with the current service and to detect their expectations from the service in the future.

\section{Road industry in the European Union and in Croatia}

\subsection{Analysis of the road industry in the European Union}

Road transport has a central role in the growth of European economy. It provides about 5 million jobs and generates turnover that is equal to $2 \%$ of EU's gross domestic product (European Commission, 2012).

The road transport sector in the EU currently is faced with the following problems:

- Drivers are faced with more congested roads;

- Fuel prices are still rising;

- Road users expect safer and more secure roads as well the working conditions (European Commission, 2012).

The EU has liberalised transport market for goods and for passengers in 1998. Related to that, a transporter from the EU has to hold Community licence if he wants to carry out transport operations throughout the Union (European Commission DG for Energy and Transport, 2006). 


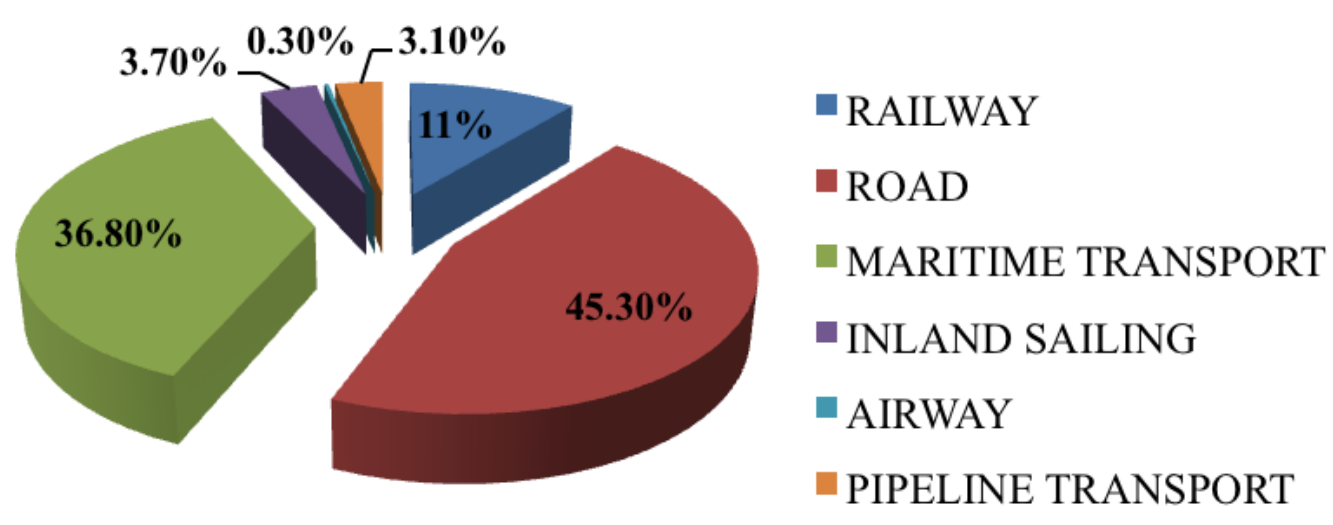

Fig. 1. Structure of cargo transport by transport mode in European Union, 2011

In Fig. 1 it can be seen that road transport has a major role in the transport of cargo in the EU and its share in all transported cargo in 2011 was 45,30\%. If we observe only the road transport, it is evident that national transport activities are most important, due to their share of $67 \%$. The rest is divided into international transport or, more precisely, into the: bilateral international transport (76\%), cross trade (20\%) and cabotage (4\%) (European Commission DG for Mobility and Transport, 2011).

\begin{tabular}{|l|l|l|l|l|l|}
\hline Year & $\begin{array}{c}\text { Total civil } \\
\text { aviation }\end{array}$ & $\begin{array}{c}\text { Road } \\
\text { transport }\end{array}$ & Railways & $\begin{array}{c}\text { Total } \\
\text { navigation }\end{array}$ & $\begin{array}{c}\text { Other } \\
\text { transports }\end{array}$ \\
\hline 2006 & $12,3 \%$ & $71,1 \%$ & $0,6 \%$ & $15,2 \%$ & $0,9 \%$ \\
\hline 2007 & $12,5 \%$ & $70,9 \%$ & $0,6 \%$ & $15,2 \%$ & $0,8 \%$ \\
\hline 2008 & $12,7 \%$ & $70,6 \%$ & $0,6 \%$ & $15,3 \%$ & $0,9 \%$ \\
\hline 2009 & $12,3 \%$ & $71,7 \%$ & $0,6 \%$ & $14,6 \%$ & $0,8 \%$ \\
\hline 2010 & $12,4 \%$ & $72,1 \%$ & $0,6 \%$ & $14,1 \%$ & $0,8 \%$ \\
\hline
\end{tabular}

Tab. 1. $\mathrm{CO}_{2}$ Emissions from Transport in EU 27 by transport mode, 2006-2010

One of the major problems of the road transport is its huge congestion. Tab. 1 shows that it has a major role in congestion, caused by different transport modes, with the share of $72,1 \%$ in 2010. Congestion costs in the European Union are equivalent to more than $1 \%$ of GDP. Due to that, the EU transport policies are defining more rigorous rules for the road transport operators. It is predicted that the use of trucks with EURO 6 standard will reduce the congestion from road transport more than $60 \%$. Also, the EU is financing R\&D programmes which are developing standards for vehicles and infrastructure for the development of the electric transport (European Commission, 2012). The EU needs to improve efficiency of the transport and optimise capacity use with the aim of reducing the congestion. 
Bendekovic, J.; Simonic, T. \& Naletina, D.: Importance of Marketing Strategy for ...

The main objective of transport policy in the EU is to develop conditions for efficient and safe operations with low impact on environment. One of the measures is further incentive for the development of the TEN-T network and numerous incentive innovative programmes that should result in a decrease of $\mathrm{CO}_{2}$ emissions.

\subsection{Analysis of road industry in Croatia}

Croatian road transport has developed more rapidly than other transport sectors; its leading share in land transport has been a trend in Croatia over many years (Vukadinovic, 2014). Faster growth of the transport fleet than that of the road network is also evident. Quality of the road network has improved since the Public Roads Construction and Maintenance Programme was adopted (Croatian Chamber of Economy - Transport and Communications Department, 2010).

Administrative measures that are implemented in the European Union require that transporters purchase trucks with lower emission of harmful substances which have ultimately influenced the reduction of vehicles with the highest emissions in total fleet of Croatian road transport operators (Vukadinovic, 2014). Most imports and exports are directed to Western Europe; majority amount of goods are transported to geographically close countries.

\begin{tabular}{|c|c|c|c|c|c|}
\hline & $\mathbf{2 0 0 8}$ & $\mathbf{2 0 0 9}$ & $\mathbf{2 0 1 0}$ & $\mathbf{2 0 1 1}$ & $\mathbf{2 0 1 2}$ \\
\hline $\begin{array}{c}\text { Passengers carried } \\
\text { (000) }\end{array}$ & 62064 & 58493 & 56419 & 25561 & 52293 \\
\hline $\begin{array}{c}\text { Goods carried } \\
\text { (000 t) }\end{array}$ & 110812 & 92847 & 74967 & 74645 & 65439 \\
\hline $\begin{array}{c}\text { Passengers - } \\
\text { kilometres (000) }\end{array}$ & 4093489 & 3437996 & 3284418 & 3145021 & 3249078 \\
\hline $\begin{array}{c}\text { Tonne-kilometres } \\
\text { (mln.) }\end{array}$ & 11042 & 9429 & 8780 & 8926 & 8649 \\
\hline
\end{tabular}

Tab. 2. Road transport of passengers and goods in Croatia, 2008-2012

From the data in Tab. 2 significant fall in the transport of cargo can be seen, as a result of the global crisis. The value of transported cargo in 2012 is $40 \%$ less than the value in 2008. It is important to mention that other modes of transport are also suffering the significant fall in demand for their services. Despite that, road transport still has a major role in the transport of cargo and that can be seen in Fig. 2. Main characteristics of Croatian road industry are its fragmentation and high number of the transporters with only two or one vehicle (Zibret \& Corak, 2012). 


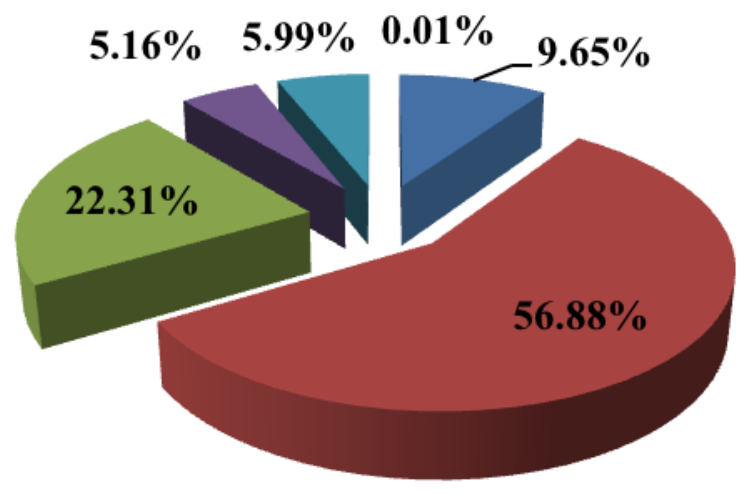

- RAILWAY

- ROAD

MARITIME TRANSPORT

- INLAND NAVIGATION

- PIPELINE TRANSPORT

- AIRWAY

Fig. 2. Structure of cargo transport by transport mode in Croatia, 2012

In order to raise the quality of cargo transport by road it is necessary to reduce the number of 'black' vehicles (vehicles with EURO 4 or less standard), ensure successful cooperation of road transporters with the competent institutions and to motivate Croatian road transport operators to merger with the aim to raise their competitiveness in the foreign market.

\section{The role of marketing in the improvement of business performance for Croatian road transport companies}

\subsection{Choice of market strategy and business goals}

Determining the market strategy starts together with the defining of the basic aim of the company business or, more precisely, the market segment in which it wants to operate. After that, internal and external market analysis should be conducted, which includes defining the strengths and weaknesses of the company and the opportunities and threats that exists in the market. Results of this analysis will lead the company towards the achievement of the defined goals (SPOET, 2005).

When we are observing the market of transport services we should know what we want to achieve and which position we want to establish. Due to that, we can choose between the following: to be a transporter in the domestic, international or both markets; to be a transporter exclusively or to offer additional services as well; to be a transporter of the particular type of cargo (transport of dangerous goods, liquids, transport of goods under controlled temperature regime). Defined business goals should be achievable within a maximum of two or three years; realistic and measurable.

One of the basic marketing tenets claims that there is no one big market, but rather there are a lot of small markets and for each a different approach is required. Therefore it is very important to find the segment whose needs and desires could be satisfied in the best way. That is why most companies today have moved away from 
mass marketing and focused their efforts on marketing segmentation and on specific target segments, adjusting their marketing strategy to each of them (Renko, 2009).

Once defined, the different market segments require the use of the following guidelines: the area where transport is conducted, characteristics of transported cargo, buyers of the transport service and services.

The segment should be large enough and different from others in order to ensure better and easier identification and differentiation. With the aim of strengthening its market position and increasing market share, a company's strategy might be:

- policy of low prices in order to increase market share;

- cooperation with other companies in order to expand the portfolio of services;

- offer of new services;

- employment of drivers with international experience;

- cancellation of services that bring low profits.

It is possible to distinguish four basic strategies for companies which are transporting goods by road, and they are as follows: subcontracting strategy, specialization strategy, organization of private transport network and strategy of expanding logistics services.

\subsection{Marketing plan}

Marketing plan is a dynamic document that should be changed as new opportunities appear. The plan should be distributed to everyone involved in marketing, including people both inside and outside the label. It is important that everyone involved understand what is being done in other departments and how synergy is created when all the elements come together (Hutchison et al, 2010). A marketing plan is a document that presents all operational plans and marketing activities; developed and executed by different marketing managers (Changchien \& Lin, 2005). It determines which market activities should be carried out, who enforces them, who is responsible and to what point.

A good marketing plan provides a thorough overview of the market situation, opportunities for the company, as well as the goals that company wants to achieve. All employees should be introduced to the content of the marketing plan and each employee to those segments that are in his sphere of responsibility. The goals of a marketing plan must be achievable, realistic, motivating and with clearly defined assignments for the persons responsible for its implementation.

From all of the above, it can be concluded that each employee must in some way participate in its creation. Company management will certainly have a greater impact in the part of the plan that is related to the strategic guidelines, middle management for the tactical part, while lower management and other employees will participate more fully in the operative part of the plan. It is important that employees accept marketing as a tool that helps in business, not as a task and obligation that wastes their valuable time. 


\section{Research on the service quality for the final users in the Croatian road industry}

\subsection{Goals and methods of the research}

The quality of transport services must be planned, implemented and controlled through three dimensions: dependence, flexibility and innovation. A company that aims to provide quality services must be focused on what the user specifies as a quality, and not only on the attitudes of employees and management about what is good and quality service. The meaning of quality is different for different users. Perceived quality of services does not occur suddenly, it is formed cumulatively over numerous contacts with the service and service companies.

The successful quality management system during the transport process is determined by: inadequate information systems, functional or organizational constraints within the company, lack of a database for the support of the decisionmaking process of the quality system, lack of understanding by the management about the benefits that quality system will ensure, insufficient employees, lack of understanding for customers' expectations from the service, lack of control in the activities outside the company that directly affect the internal operations.

Companies that want to implement the quality system successfully must: have a clear vision of what a system of quality means to them, train employees that are directly involved in the implementation of quality systems and define goals and make plans for achievement of the stated goals.

The goals of primary research are the following:

1. To determine the value for customers based on three groups of service characteristics (fee for service, quality of service and service availability), or eight sub-items (cost of transport services, taking care about the customer, the stability of the supply chain, complete delivery, references, flexibility, respecting the defined terms, integrated services);

2. To measure customer satisfaction with the current service and to detect their expectations for the service in the future.

\subsection{Results of the research}

The research was divided into two groups. The first one was assigned for the middle management and the second one for the operational staff (procurement and logistics referents) who are directly involved in the business of ordering trucks and monitoring the transport process.

4.2.1 Research with the aim of gathering information about the preferences of the users of transport services

To confirm the importance of certain elements of transport services, the primary research was done through a questionnaire. The questionnaire was sent to the addresses of 37 managers (directors/heads of procurement and logistics departments) 
of the largest food and retail companies in the Republic of Croatia. 35 responses were received, which represents a success rate of $95 \%$ and is the above average turnout. In the questionnaire three groups of elements of service were formed: service price, service quality and availability of services.

Due to results, the most important elements to customers are: stability of the supply chain, timely delivery of goods to the required location and flexibility of the service. Carrier's care for their needs is also highly rated. They expect partnership and active approach of the transporter during transport. Price of the service usually becomes decisive criteria when the user is satisfied with the quality of service.

\subsubsection{Research on the satisfaction level of services users and their expectations from} providers of transport services

The aim of this research is to define guidance how to improve the level of service through specified period of time and thus fulfil the conditions for the realization of higher added value for the customers.

The survey questionnaire was sent to 145 customers from the list of users of transport services. 89 responses $(61 \%)$ were received. The questionnaire was filled by the responsible employees, mostly from the procurement and logistic department, which are in charge of the arrangement of transport capacities and observation of the entire supply chain. All customers are located within eight different industries that are detected as a target group of the transport company.

Based on the results of the research it can be concluded that users are generally satisfied with the quality of transport services, just $10 \%$ of the respondents think that service is not at a satisfactory level. They are particularly satisfied with the compliance of the drivers and other staff from the transport company. It can be noted that there is a relatively large number of respondents (almost 20\%) who believe that they are not getting enough benefits for the paid price of the service. $70 \%$ of respondents, despite the current satisfaction, expect improvements of the service in the future. This reflects that it is necessary to improve business operations continually and seek the best marketing solutions for the customers.

The price of service is a very important factor, as $85 \%$ define it as decisive criteria in choosing a transporter. A large number of respondents expects that, in the future, the transporter should offer integrated logistics services. It means that today's users of transport services want to organise the entire supply chain with just one contract. Now they need at least two or three service companies to be able to do that.

\section{Conclusion}

The process of globalization has strongly affected the market of transport services but road transport has still major role in the inland transport of cargo in the European Union, as well in Croatia. The financial crisis had a strong impact on this industry as well, and taking into consideration that Croatia has joined the European Union which increased the competition, there was a clear need for research on the 
sources of competitive advantage of road transporters, especially of possibility of achievement competitive advantage based on the adequate marketing strategy.

The quality of transport services must be planned, implemented and controlled through three dimensions: dependence, flexibility and innovation. A company that aims to provide quality services must be focused on what the user specifies as a quality, and not only on the attitudes of employees and management about what is good and quality service. For successful implementation of marketing strategy it is important that all employees accept marketing as a tool that helps in business, not as a task and obligation that wastes their valuable time. Companies that want to implement the quality system successfully must: have a clear vision of what a system of quality means to them, train employees that are directly involved in the implementation of quality systems and define goals and make plans for achievement of the stated goals.

Primary research was conducted with the aim to:

1. Determine the value for customers based on three groups of service characteristics (fee for service, service quality and service availability), or eight sub-items (cost of transport services, taking care about the customer, the stability of the supply chain, complete delivery, references, flexibility, respecting the defined terms, integrated services);

2. Measure customer satisfaction with the current service and to detect their expectations from the service in the future.

The primary research was done through a questionnaire and it was sent to the addresses of 37 managers and 145 customers. The research results indicate that almost $53 \%$ of respondents highlight service quality as decisive criteria in the process of choosing a transporter. Finally, we can conclude that the price of transport service stands out as the key factor when selecting a transportation service provider. It is an important element in this process, but surely not the crucial one. At least not until a consumer receives the required level of service quality for the asking price. Otherwise, the consumer will opt for somewhat more expensive provider if it ensures supply chain continuity, necessary level of available capacities and flexibility.

\section{References}

Changchien, S. W. \& Lin, M. (2005). Design and implementation of a case-based reasoning system for marketing plans, Expert Systems with Applications, Vol. 28, No. 1, (May 2005) 43-53, ISSN: 0957-4174

Croatian Bureau of Statistics (2013). Statistical Yearbook of the Republic of Croatia, Available from: http://www.dzs.hr/Hrv_Eng/ljetopis/2013/sljh2013.pdf Accessed: 2014-07-01 
Bendekovic, J.; Simonic, T. \& Naletina, D.: Importance of Marketing Strategy for ...

Croatian Bureau of Statistics (2013). Transport i komunikacije u 2012 (Transport and Communication in 2012). Available from: http://www.dzs.hr/Hrv_Eng/publication/2013/SI-1493.pdf Accessed: 2014-07-05

Croatian Chamber of economy - transport and communications department (2010). Road, rail and air transport. Available from: https://www.hgk.hr/wpcontent/blogs.dir/1/files_mf/1278319729ceste_zeljeznice_zracni_2009.pdf Accessed: 2014-07-01

European Commission (2013). EU transport in figures, Statistical pocketbook 2013, Publications office of the European Union, ISBN: 978-92-79-28860-9, Belgium Available from: http://ec.europa.eu/transport/facts-fundings/statistics/pocketbook2013_en.htm Accessed: 2014-06-14

European Commission (2012). Road Transport: A change of gear. Available from: http://ec.europa.eu/transport/modes/road/doc/broch-road-transport_en.pdf. Accessed: 2014-07-01

European Commission DG for Mobility and Transport (2011). Road freight transport vademecum 2010 Report. Available from: http://ec.europa.eu/transport/modes/road/ Accessed: 2014-07-18

European Commission DG for Energy and Transport (2006). Road Transport Policy: Open roads across Europe. Available from: http://ec.europa.eu/transport/road/doc/road_transport_policy_en.pdf Accessed: 201406-25

Hutchison T.; Allen, P. \& Macy, A. (2010). Record Label Marketing, Focal Press, second edition, ISBN: 978-0-240-81238-0, United Kingdom

Renko, N. (2009). Strategije marketinga (Marketing strategies), Naklada Ljevak, ISBN: 978-953-303-079-1, Zagreb, Hrvatska

SPOET (2005). Ekonomija upravljanja - marketing u prijevozu cestom (Economy Management - marketing in road transport), Transportkomerc, Zagreb, Hrvatska Vukadinovic, D. (2014). Izazovi liberalizacije tržišta cestovnoga teretnog prijevoza (Challenges of Liberalisation on the Road Transport Market). Suvremeni promet, Vol. 34, No. 1-2, pg. 70-78, ISSN: 0351-1898

Vukadinovic, D. (2014). Svojstva međunarodnog tržišta cestovnoga teretnog prijevoza (Characteristics of the International Road Freight Transport Market). Suvremeni promet, Vol. 34, No. 1-2, pg. 62-69, ISSN: 0351-1898 